\title{
PENYELESAIAN KREDIT BERMASALAH PT. BANK PEMBANGUNAN DAERAH (BPD) SUMBAR CABANG ALAHAN PANJANG KABUPATEN SOLOK
}

\author{
Ilham Febriansyah, Afriyeni \\ Akademi Keuangan dan Perbankan Padang \\ Afriyeni.yen@gmail.com
}

\begin{abstract}
In line with the rapid development in Indonesia especially economic evelopment, the financial institutions such as banks is one tool to help the smooth economy as a provider of capital in the form of credit. Banks as financial institutions are never separated from credit because the amount of credit disbursed will determine the bank's profit. If the bank does not disburse its credit well while the funds collected from the deposit enough, it will not be good for the bank because the funds will settle will harm the bank. Loans made by banks do not always go smoothly and so does PT. Bank Pembangunan Daerah (BPD) Sumatera Barat Cabang Alahan Panjang Kabupaten Solok because one day the bank is difficult to ask the installment of the debtor on something Therefore, the management must be done professionally with the help of strict supervision in anticipation of problem loans. Non performing loans are caused by customers who can no longer pay their mortgage, either the interest or the principal of the loan in accordance with the agreed agreement between both parties, namely between the bank with the customer and the nonperforming loans will result in losses to the bank because the fund can not channeled back by the bank, then this study was conducted aims to determine the causes of problem loans and their completion. The method used by the authors in this study is observation with direct observation in the field, interviews with the bank and literature study by looking at the readings related to the research. The results showed that the causes of nonperforming loans at PT Bank Pembangunan Daerah (BPD) Sumatera Barat Cabang Alahan Panjang Kabupaten Solok is a factor of its customers. Most of its customers are experiencing crop failure due to natural disasters. Settlement of Non Performing Loans at PT Bank Pembangunan Daerah (BPD) Sumatera Barat Cabang Alahan Panjang Kabupaten Solok is by Rescheduling or rescheduling, Reconditioning or re-requirements and Restructuring or rearrangement.
\end{abstract}

Keyword : Non Performing Loan (NPL), Causes of Troubled Credit, Credit Settlement. 


\section{LATAR BELAKANG}

Perbankan sebagai subsistem bagi perekonomian negara mempunyai peranan cukup penting sebab dengan adanya perbankan pertumbuhan ekonomi suatu negara dapat meningkat, bahkan dalam kehidupan masyarakat sebagian besar melibatkan jasa dari perbankan.Sejalan dengan pesatnya pembangunan di Indonesia khususnya pembangunan ekonomi, maka lembaga keuangan seperti bank merupakan salah satu alat untuk membantu kelancaran ekonomi sebagai penyedia modal dalam bentuk pemberian kredit. Bank sebagai lembaga keuangan tidak pernah terlepas dari kredit sebab jumlah kredit yang disalurkan akan menentukan keuntungan bank.

Menurut Undang-undang (RI Nomor 10, 1998 Tentang Perbankan)Bank adalah badan usaha yang menghimpun dana dari masyarakat dalambentuk simpanan dan menyalurkannyakepada masyarakat dalam bentuk kredit dan atau bentuk-bentuk lainnya dalam rangka meningkatkan taraf hidup rakyat banyak.

Pemberian kredit yang dilakukan bank tidak selalu berjalan dengan lancar dan baik seperti halnya dengan PT Bank Pembangunan Daerah (BPD) Sumatra Barat Cabang Alahan Panjang Kabupaten Solok karena suatu saat pihak bank mengalami kesulitan untuk meminta angsuran dari pihak debitur karena sesuatu hal.Oleh karena itu, pengelolaannya harus dilakukan secara profesional dengan dibantu pengawasan yang ketat guna mengantisipasi kredit yang bermasalah.Menurut (Nurul, (2012) kredit bermasalah adalahsuatu keadaan dimana nasabah sudah tidak sanggup membayar sebagian atau seluruh kewajibannya kepada bank seperti yang telah diperjanjikannya.

Bank dalam setiap penyaluran kreditnya tidaklah semuanya berjalan lancar sebagaimana yang diharapkan, begitu juga dengan BPD Sumbar Cabang Alahan Panjang Kabupaten Solok dalam penyaluran kreditnya belum tentu semua kredit atau pembiayaan yang di berikan selalu lancar dan bebas dari kredit bermasalah karena mayoritas dari nasabah BPD Sumbar Cabang Alahan Panjang Kabupaten Solok adalah para petani dan pedagang. Kebanyakan dari mereka melakukan pinjaman kredit berupa kredit modal kerja yaitu, para petani melakukan pinjaman untuk membeli pupuk dan bibit untuk ladang-ladang mereka dan para pedagang yang melakukan pinjaman untuk membeli persediaan warung-warung mereka tetapi para petani dan pedagang tersebut banyak yang mengalami kesulitan dalam mengembalikan cicilan kreditnya karena bisa dilihat dari kehidupan mereka sangat sederhana ditambah lagi bagi para petani mereka harus menunggu lebih kurang 3 (tiga) bulan dalam hasil panennya terkadang bisa lebih karena tergantung dari tanaman apa yang ditanam dan bagi para pedagang mereka juga tidak mungkin mendapatkan laba yang lebih setiap harinya sedangkan angsuran cicilan kredit mereka harus bayar tiap bulannya, maka dari itu sering terjadinya kredit bermasalah dikalangan para petani dan pedagang ini disebabkan diantara mereka yang sudah tidak mampu lagi dalam memenuhi kewajibannya terhadap bank.

MenurutOlyvia, (2013) menyatakan bahwa sebab-sebab timbulnya kredit bermasalah meliputi kelemahan dari sisi intern debitur dapat disebabkan oleh itikad tidak baik dari debitur, menurunnya usaha debitur mengakibatkan turunnya kemampuan debitur untuk membayar angsuran, debitur tidak mempunyai pengetahuan serta pengalaman yang cukup untukmengelola usaha, sehingga usaha 
debitur tidak berjalan baik dan ketidakjujuran debitur dalam penggunaan kredit untuk produktif menjadi kredit konsumtif yang tidak sesuai dengan tujuan semula dalam perjanjian kredit, kelemahan dari sisi intern bank atau lembaga keuangandapat disebabkan oleh itikad tidak baik dari petugas bank atau lembaga keuangan untuk kepentingan pribadi, seperti pegawai bank atau lembaga keuangan merealisir kredit debitur yang memberi imbalan atas pencairankredit tersebut, kurang mampunya petugas bank atau lembaga keuangan dalam pengelolaan pemberian kredit mulai dari pengajuan permohonan sampai pencairan kredit, kelemahan dan kurang efektifnya petugas bank atau lembaga keuangan membina debitur, sehingga debitur mudah memanfaatkan celah ini untuk mencoba melakukan pelanggaran maupun ingkar janji (wanprestasi) dan kelemahan dari sisi ekstern bank atau lembaga keuangan dapat disebabkan perubahan-perubahan yang terjadi karena bencana alam yang dapat menyebabkan kerugian besar bagi debitur dalam usahanya, misalnya banjir, tanah longsor,kebakaran, dan lain sebagainya, perubahan-perubahan eksternal lingkungan (environment), perubahan ekonomi karena krisis moneter yang berpengaruh terhadap usaha debitur dan krisis moneter yang dapat menyebabkan terjadinya inflasi serta membuat nilai mata uang menurun terhadap mata uang asing, misalnya harga barang-barang naik yang menyebabkan daya beli masyarakat menurun.

PT. BPD Sumbar cabang Alahan Panjang Kabupaten Solok mempunyai upaya untuk menyelamatkan kredit bermasalah dengan caraRescheduling atau penjadwalan ulang, Reconditioning atau persyaratan ulang dan Restructuringatau penataan ulang.Menurut(Uswatun, 2012)Reschedulling atau penjadwalan ulang adalah perubahan syarat kredit yang hanya menyangkut jadwal pembayaran atau jangka waktu termasuk masa tenggang dan perubahan besarnyaangsurankredit, Reconditioningatau persyaratan ulang adalah perubahan seluruh syarat-syarat kreditmeliputi perubahan jadwal pembayaran, jangka waktu, tingkat suku bunga, penundaan sebagian atau seluruhnya serta persyaratan-persyaratan lainnya dan Restructuringatau penataan ulang adalah perubahan syarat kredit yang menyangkut penambahan dana bank, konversi sebagian atau seluruh bunga kredit, konversi sebagian atau seluruh kredit menjadi penyertaan bank atau mengambil partner lain.

Kredit yang disalurkan harus di kelola dengan baik untuk meminimalisir terjadi kerugian sehingga akan memberikan dampak positif terhadap perkembangan dan kemajuan ekonomi daerah.Kredit bermasalah dalam jumlah besar dapat menyebabkan kerugian terhadap suatu bank tersebut karena dana tidak dapat diputar kembali. Kriteria penilaian tingkat kesehatan denganRasio Non Performing Loan(NPL) dapat dilihat pada tabel dibawah ini (Tabel 1):

\section{Tabel 1}

Kriteria penilaian tingkat kesehatan dengan RasioNPL BankMenurut Surat Edaran Bank Indonesia (BI) Nomor 12/11/DPNP Tanggal 31 Maret 2010

\begin{tabular}{|c|c|}
\hline Rasio & Predikat \\
\hline NPL kecil dari 5\% & Sehat \\
\hline NPL besar dari 5\% & Tidak sehat \\
\hline
\end{tabular}

Sumber : SE BI Nomor 12/ 11 /DPNP tanggal 31 Maret 2010 
Kriteria penilaian tingkat kesehatan bank menggunakan Rasio Non Performing Loan (NPL) sesuai dengan Surat Edaran Bank Indonesia (BI) menetapkan nilai NPL maksimum adalah sebesar 5\%, apabila bank melebihi batas yang diberikan maka bank tersebutdikatakan tidak sehat.(SE BI Nomor 12/ 11 /DPNP tanggal 31 Maret 2010).

Dalam menyalurkan kreditnya BPD Sumbar Cabang Alahan Panjang Kabupaten Solok memiliki beberapa jenis kredit yaitu kredit modal kerja, kredit konsumtif dan kredit investasi.

Dalam penelitian ini difokuskan kepada kredit modal kerja dan kolektibilitas kredit modal kerja pada PT. Bank BPD Sumbar Cabang Alahan Panjang Kabupaten solok dari tahun 2013 sampai dengan tahun 2017 adalah sebagai berikut:

\section{Tabel 2}

Jumlah kredit modal kerja bermasalah PT.BPD Sumbar Cabang Alahan Panjang Kabupaten Solok tahun 2013 sampai dengan Tahun 2017

(Dalam jutaan rupiah)

\begin{tabular}{|c|c|c|c|c|}
\hline No & Tahun & $\begin{array}{l}\text { Total Kredit } \\
\text { Yang Disalurkan }\end{array}$ & $\begin{array}{l}\text { Jumlah Kredit } \\
\text { Bermasalah }\end{array}$ & Persen (\%) \\
\hline 1 & 2013 & 135.929 & 1.138 & 0,84 \\
\hline 2 & 2014 & 153.342 & 1.987 & 1,30 \\
\hline 3 & 2015 & 163.620 & 3.305 & 2,02 \\
\hline 4 & 2016 & 171.025 & 2.782 & 1,66 \\
\hline 5 & 2017 & 190.339 & 2.664 & 1.40 \\
\hline
\end{tabular}

Sumber Data :PT. BPD Sumbar Cabang Alahan Panjang Kabupaten Solok

Berdasarkan tabel diatas dapat dilihat bahwa NPL BPD Sumbar Cabang Alahan Panjang Kabupaten Solok dari tahun 2013 sampai dengan tahun 2017 masih tetap rendah yaitu berada dibawah $5 \%$.

Perumusan Masalah

Berdasarkanlatarbelakang yang telah diuraikan, maka perumusan masalah dalam penelitian ini adalah "Bagaimanapenyelesaian kredit bermasalah PT. BPD Sumbar Cabang Alahan Panjang Kabupaten Solok".

\section{TINJAUAN PUSTAKA}

Bank

Bank merupakan lembaga keuangan yang berperan penting bagi perusahaan, badan pemerintahan, swasta maupun perorangan untuk menyimpan atau mendapatkan dana melalui kegiatan perkreditan dan berbagai jasa lain yang diberikan bank.Menurut (Pebriani, 2015)bank adalah badan usaha yangmenghimpun dana dari masyarakat dalam bentuksimpanan dan menyalurkan ke masyarakat dalamrangka meningkatkan taraf hidup orang banyak.

Pendapat lain tentang bank menurut (Metia, 2014) Bank di Indonesia berdasarkan Undang-undang Nomor 10Tahun 1998 tentang perbankan menyebutkan bahwa bank adalah badan usahayang menghimpun dana dari 
masyarakat dalam bentuk simpanan danmenyalurkannya kepada masyarakat dalam bentuk kredit dan atau bentuk-bentuklainnya dalam rangka meningkatkan taraf hidup rakyat banyak.

\section{Jenis-jenis, Bentuk Hukum Dan Kegiatan Usaha Bank}

Berdasarkan jenisnya bank terdiri dari duajenis yaitu, bank umum dan Bank PerkreditanRakyat (BPR).Bank umum adalah bank yang melaksanakankegiatan usaha secara konvensionaldan atau berdasarkan prinsip syariah yang dalamkegiatannya memberikan jasa dalam lalu lintaspembayaran, sedangkan BPR adalah bank yangmelaksanakan kegiatan usaha secara konvensionaldan atau berdasarkan prinsip syariah yang dalamkegiatannya tidak memberikan jasa dalam lalulintas pembayaran.Bentuk hukum bank umum danBPR dapat berupa Perseroan Terbatas (PT). Bankumum terdiri dari bank-bank umum pemerintah,bank-bank umum swasta nasional devisa,bank-bank swasta nasional nondevisa, bank-bankasing dan campuran. Kegiatan utama bankumum adalah menghimpun dana masyarakatantara lain dalam bentuk giro, deposito berjangkadan tabungan, serta menyalurkan kepada masyarakatdalam bentuk kredit. Sedangkan definisi BPRadalah bank yang melaksanakan kegiatan usahasecara konvensional atau berdasarkan prinsipsyariah yang dalam kegiatannya tidak memberikanjasa lalu lintas pembayaran.(Suliyanto, 2014)

Persyaratan modal awal yang harus disetor oleh bank umum menurut(Peraturan Otoritas Jasa Keuangan Nomor 11 POJK.03/2016, 2016)sebagaimana dimaksud dalam Pasal 28ayat (2) adalah:

a. Bank yang secara individu memenuhi salah satukriteria:

1) Bank dengan total aset sebesarRp. 10.000.000.000.000,00 (sepuluh triliun rupiah) atau lebih.adalah melakukan kegiatan usaha dalamvaluta asing dengan posisi instrumen keuanganberupa surat berharga dantransaksiderivatif dalam trading book sebesarRp. 20.000.000.000,00 (dua puluhmiliar rupiah)atau lebih.Bank yang tidak melakukan kegiatan usaha dalam valuta asing dengan posisi instrument keuangan berupa surat berharga dan transaksi derivatif suku bunga dalam trading book sebesar Rp. 25.000.000.000,00 (dua puluh lima miliar rupiah) atau lebih.

Bank yang secara konsolidasi dengan perusahaan anak memenuhi salah satu kriteria:

1) Bank yang melakukan kegiatan usaha dalamvaluta asing yang secara konsolidasi dengan perusahaan anak memiliki posisi instrumenkeuangan berupa surat berharga termasukinstrumen keuangan yang terekspos risikoekuitas atau transaksi derivatif dalamtrading book dan instrumen keuangan yangterekspos risiko komoditas dalam trading bookdan banking book sebesar Rp. 20.000.000.000,00(dua puluh miliar rupiah) atau lebih.

2) Bank yang tidak melakukan kegiatan usahadalam valuta asing namun secara konsolidasi dengan perusahaan anak memiliki posisiinstrumen keuangan berupa surat berhargatermasuk instrumen keuangan yang tereksposrisiko ekuitas dan transaksi derivatif dalamtrading book dan instrumen keuangan yangterekspos risiko komoditas dalam trading book dan banking book sebesar Rp. 25.000.000.000,00(dua puluh lima miliar rupiah) atau lebih.

Adapun persyaratan sumber modal bank umum adalah : 
1) Merupakan modal sendiri, tidak berasal dari pinjaman atau fasilitas pembiayaan dalam bentuk apapun dari bank dan pihak lain di Indonesia.

2) Tidak dari hasil kegiatan yang melanggar hukum.Bank sebagai lembaga perantara keuangan memberikan jasa - jasa keuangan baik kepada pihak yang membutuhkan dana dan pihak yang memiliki dana. Bank memiliki fungsi pokok sebagai berikut.(Yoli, 2013) :

1. Menyediakan mekanisme dan alat pembayaran yang lebih efesien dalam kegiatan ekonomi.

2. Menciptakan uang

3. Menghimpun dana dan menyalurkan kepada masyarakat.

4. Menawarkan jasa - jasa keuangan lain.

5. Menyediakan fasilitas untuk perdagangan internasional.

6. Menyediakanpelayanan penyimpananuntuk barang-barang berharga.

7. Menyediakan jasa-jasa pengelolaan dana.

\section{Kredit}

Menurut Saduldyn, (2013)Kredit merupakan kemampuan seseorang ataupun badan usahauntuk menggunakan uang, barang atau jasa yang diterima dihubungkandengan kemampuan untuk mengembalikan setelah jangka waktu tertentu.Kata kredit berasal dari kata credere yang artinya adalah kepercayaan, maksudnya apabila seseorangmemperoleh kredit, maka mereka memperoleh kepercayaan.Sementara itu, bagi si pemberi kredit artinyamemberikan kepercayaan kepada seseorang bahwa uang yang dipinjamkan pasti kembali.

Menurut Ni Made Dwi, (2014)kredit adalah penyediaan uangatau tagihan yang dapat dipersamakandengan itu, berdasarkan persetujuanpinjam meminjam antara pihak bankdengan pihak lain, peminjamberkewajiban melunasi hutangnya setelahjangka waktu tertentu dengan jumlahbunga atau bagi hasil yang telahditetapkan.

Adapun kredit menurut Chadijah, (2017)adalah penyediaan uang atau tagihan yang dapat dipersamakan dengan itu, berdasarkanpersetujuan atau kesepakatan pinjam-meminjam antara bank dengan pihak lain yangmewajibkan pihak peminjam untuk melunasi utangnya setelah jangka waktu tertentu denganpemberian bunga.

Dari defenisi diatas dapat disimpulkan bahwa kredit adalahpenyediaan uang kepada pihak ketiga atas dasar kepercayaan denganperjanjian tertulis bahwa akan dikembalikan kembali bersama bunganyaoleh peminjam sesuai dengan perjanjian yang telah disepakati.

\section{Fungsi dan Tujuan Penyaluran Kredit}

Menurut Widya, (2016) fungsi kredit yaitumemajukan arus tukar menukar barang danjasa, kredit mengaktifkan alat pembayaran yangidle atau yang tidak digunakan, kreditmenciptakan alat pembayaran baru dan kreditmengaktifkan serta meningkatkan manfaat potensiekonomi yang ada, sedangkan tujuan penyaluran kreditadalah untuk mendapatkan keuntungan yang aman, sehingga masyarakat yang meminjam danadapat memperoleh simpanannya kembali besertabunganya tanpa adanya kekhawatiran denganadanya kredit yang macet. 
Dari defenisi diatas, maka bank mempunyai peranan sangat penting dalam prekonomian modern,khususnya dibidang moneter sehingga dapat menunjang pembangunanterutama di bidang ekonomi.

\section{Unsur-unsur Pemberian Kredit}

Unsur-unsur yang terkandung didalam pemberian suatu kredit menurut (M. Fitri, 2002) adalahsebagai berikut:

1. Kepercayaan, yaitu suatu keyakinan pemberi kredit bahwa kredit yang diberikan (berupa uang,barang atau jasa) akan benar-benar diterima kembali dimasa tertentu dimasa yangakan datang. Kepercayaan ini diberikan oleh bank, dimana sebelumnya sudahdilakukan penelitian penyelidikan tentang nasabah baik secara intern maupun ekstern, penelitian dan penyelidikan tentang kondisi masa lalu dan sekarangterhadap nasabah pemohon kredit.

2. Kesepakatan, disamping unsur percaya didalam kredit juga mengandung unsur kesepakatanantara si pemberi kredit dengan si penerima kredit. Kesepakatan ini dituangkandalam suatu perjanjian, dimanadari masingmasing pihak menandatangani hak dankewajibannya.

3. Jangka waktu, setiap kredit yang diberikan memiliki jangka waktu tertentu, jangka waktu mencakup masa pengembalian kredit yang telah disepakati. Jangka waktutersebut bisa berbentuk jangka pendek, jangka menengah atau jangka panjang.

4. Resiko, adanya suatu tenggang waktu pengembalian akan menyebabkan suatu resikotidak tertagihnya pemberian kredit. Semakin panjang suatu kredit semakinbesar resikonya demikian pula sebaliknya.Resiko ini menjadi tanggungan bank,baik resiko yang disengaja oleh nasabah yang lalai maupun oleh resiko yangtidak disengaja.Misalnya terjadi bencana alam atau bangkrutnya usaha nasabahtanpa ada unsur kesengajaan lainnya.

5. Balas Jasa, merupakan keuntungan atas pemberian suatu kredit atau jasa tersebut yang kitakenal dengana nama bunga.Menurut (Bambang, (2014)unsur-unsur kredit adalah sebagai berikut :

1)Adanya Suatu penyerahan ataupenyediaan uang maupun tagihan yang dapat menimbulkan tagihan tersebut kepadapihak lain, dengan harapan dalam pemberian pinjaman ini bank akan memperolehsuatu tambahan nilai dari pokok pinjaman tersebut, yang berupa bunga sebagaipendapatan bagi bank yang bersangkutan.

2) Adanya suatu perjanjian yang salingmempercayai bagi kedua belah pihak, di mana masing-masing pihak akan memenuhi kewajibannya.

3) Adanya suatu kesepakatan mengenai pelunasan hutang dan bungaakan diselesaikan dalam jangka waktu tertentu yang disepakati bersama.

4) Risiko, yaitu adanya suatu perbedaan antara pelepasan dan pengembalian prestasimenimbulkan risiko bagi pemberian kredit.

\section{Prinsip-prinsip Pemberian Kredit}

Berkaitan dengan prinsip pemberian kreditoleh bank, pada dasarnya pemberian kredit olehbank kepada nasabah berpedoman pada 2 (dua) prinsip menurut (Mutiara, 2016) yaitu :

1. Prinsip kepercayaan, dalam hal ini dapat dikatakan bahwa pemberian kredit oleh bank kepada nasabah selalu didasarkan kepada kepercayaan. Bank 
mempunyai kepercayaan bahwa kredit yang diberikan bermanfaat bagi nasabah dan bankpercaya nasabah mampu melunasi utang kredit beserta bunga dalam jangka waktu yang telah ditentukan.

2. Prinsip kehati-hatian, bank dalam menjalankan kegiatan usahanya termasuk pemberian kredit harus selalu berpedoman dan menerapkan prinsip kehatihatian. Prinsip ini antara lain diwujudkan dalam bentuk penerapan secara konsisten berdasarkan itikad baik semua persyaratan dan peraturan perundangundangan yang terkait dengan pemberian kredit. Prinsip kehati-hatian adalah suatu asas atau prinsip yang menyatakan bahwa dalam menjalankan fungsi dan kegiatan usahanya bank wajib bersikap hati-hati dalam rangka melindungi dana masyarakat yang dipercayakan pada bank tersebut. Dalam ketentuan prinsip kehati-hatian bank, yaitu adanya kewajiban bagi bank menyediakan informasi mengenai kemungkinan timbulnya resiko kerugian sehubungan dengan transaksi nasabah yang dilakukan melalui bank.

Menurut Rahmad, (2015)prinsip-prinsip pemberian kredit adalah prinsip analisis 5C yaitu : Character adalah sifat atau watak dari orang yang akan diberi kredit apakah dapat di percaya apa tidak karena hal ini dilihat dari latar belakang dan gaya hidup. Capacity, adalah kemampuan calon nasabah dalam bidang bisnis terutama dengan usaha yang dijalani dikaitkan dengan tingkat pendidikan serta pemahaman tentang ketentuan-ketentuan pemerintah.Capital, adalah analisis dari keefektifan penggunaan modal dilihat dari laporan keuangan dengan melakukan pengukuran likuiditas, solvabilitas, rentabilitas dan juga melihat dari mana saja sumber modal saat ini. Collateraladalah jaminan yang diberikan nasabah, baik fisik maupun non fisik yang harus diperiksa keabsahannya sehingga jika terjadi masalah dapat segera digunakan.Condition Of Economy, merupakan analisis terhadap keadaan ekonomi dan politik saat ini dan yang akan datang sesuai sektor usaha serta prospek usaha tersebut.

\section{Jenis-jenis Kredit}

Dalam memberikan kredit, bank membagi kredit nya menjadi tiga macam menurutkegunaannya, yaitu kredit modal kerja, kredit investasi, dan kredit konsumsi.Denganpembagian kredit menurut kegunaannya bank dapat menyesuaikan layanan pemberiankreditnya sesuai dengan maksud dan tujuan peminjamnya.

Secara garis besar, menurut Randy, (2014)jenis-jenis kredit dapat dibagi menjadi beberapa golongan menurut penggunaannya yaitu, kredit modal kerja, kredit investasi dan kredit konsumsi, bank Garansi dan lain-lain.

Menurut Yoda, (2008) kredit bila dilihat dari segi penggunaannya dapat dibagi menjadi tiga, yaitu :

1) Kredit modal kerja, yaitu kredit berjangka waktu pendek yang diberikan oleh bank kepada perusahaan yang membutuhkan modal kerja untuk memperlancar kegiatan operasional perusahaan.

2) Kredit Investasi, kredit ini adalah kredit jangka menengah atau panjang yang diberikan oleh bank kepada pihak perusahaan yang membutuhkan dana untuk investasi atau penanaman modal.

3) Kredit konsumsi, yaitu kredit yang diberikan dengan maksud untuk memperlancar kegiatan yang sifatnya konsumtif, seperti kredit pemilikan 
rumah, kredit pemilikan kendaraaan bermotor, credit card, dan kredit konsumtif lainnya. Jangka waktu kredit konsumsi ini bisa jangka pendek, menengah maupun jangka panjang.

Jenis kredit secara umum yang diberikan oleh bank kepada calon nasabah secara umum adalah kredit modal kerja, kredit investasi dan kredit konsumsi.

\section{METODE PENELITIAN}

Adapun metode penelitian yang digunakan dalam penelitian ini adalah sebagai berikut :

Metode Pengumpulan Data

a. PenelitianKepustakaan (Library Research), yaitu penelitian dengan membaca buku-buku, literatur, laporan-laporan tertulis dan tulisan-tulisan ilmiah yang adakaitannya dengan masalah yang dibahas.

b. Penelitian Lapangan (Field Research), yaitu pengumpulan data dengan pengamatan secara langsung terhadap objek yang diteliti dengan menempuh cara sebagai berikut :

1) Observasi, yaitu cara pengumpulan data dengan pengamatan secara langsung terhadap objek yang diteliti.

2) Wawancara, yaitu melakukan tanya jawab dengan pihak-pihak yang berkepentingan pada perusahaan yang diteliti dalam mendapatkan data yang diperlukan.

MetodeAnalisis Data

Dalam menganalisa data, penulis menggunakan metode analisis data kualitatif yaitu menggambarkan, memahami dan menjelaskan data yang diteliti pada PT. BPDSumbar Cabang Alahan Panjang Kabupaten Solok.

\section{HASIL DAN PEMBAHASAN}

\section{Penyebab Kredit Bermasalah}

Kreditbermasalah menggambarkan situasi, dimana persetujuanpengembalian kredit mengalami risiko kegagalan, bahkan cenderungmenuju atau mengalami kerugian.Hal-halyang menjadi penyebab timbulnya kredit bermasalah tersebut perlu disadarioleh bank agar bank dapat mencegah atau menangani dengan baik.

Menurut Sjafitri, (2011)penyebab timbulnyakredit bermasalah dapat dikelompokkanatas 3 golongan yaitu :

1. Faktor intern bank, yaitu penyelenggaraan analisis kredit yang kurang mampu atau karena pimpinan bank mendapat tekanan dari pihak luar, pimpinan bank terlalu agresif untuk menyalurkan kredit dan campur tangan para pemegang saham yang berlebihan dalamproses pengambilan keputusan pemberian kredit.

2. Ketidaklayakan debitur, yaitu debitur menderita sakit berat, kecelakaan atau meninggal dunia dan penghasilan tetap terganggu.

3. Pengaruh faktor ekstern, yaitu penurunan kondisi ekonomi, Bencana alam dan peraturan pemerintah.

Pada PT. BPD Sumbar Cabang Alahan Panjang Kabupaten Solok kredit bermasalah terjadi disebabkan oleh faktor ekstern yaitu adanya penurunan kondisi ekonomi nasabah dan ada karena peraturan pemerintah yang menaikan tingkat 
suku bunga, tetapi kebanyakan timbulnya kredit bermasalah karena faktor bencana alam yaitu, para petani yang gagal panen karena adanya perubahan cuaca dan hujan curah hujan yang tinggi dalam artian hujan yang turun terus-menerus selama beberapa hari.

BPD Sumbar Cabang Alahan Panjang Kabupaten Solok memiliki beberapa macam kredit diantaranya kredit modal kerja, dimana kredit modal kerja ini diberikan oleh pihak bank kepada nasabah untuk menambah modal dari usaha mereka.

Menurut Ratna, (2013) kredit modal kerja adalah kredit yang digunakan untuk keperluan meningkatkan produksi dalam operasionalnya atau merupakan kredit yang digunakan sebagai modal usaha. Biasanya kredit jenis ini berjangka waktu pendek yaitu tidak lebih dari 1 (satu) tahun.Selain itu, kredit modal kerja adalah kredit yang digunakan untuk membiayai kebutuhan modal kerja nasabah.

Adapun kolektibilitas kredit modal kerja pada Bank BPD Sumbar Cabang Alahan Panjang Kabupaten Solok dari tahun 2013 sampai dengan tahun 2017 bisa dilihat pada tabel berikut:

\section{Tabel 3}

Kolektibilitas kredit modal kerja PT.BPD Sumbar Cabang Alahan Panjang Kabupaten Solok tahun 2013 sampai dengan tahun 2017 (Dalam jutaan rupiah)

\begin{tabular}{|c|c|c|c|c|c|c|c|}
\hline \multirow[t]{2}{*}{ Tahun } & \multicolumn{5}{|c|}{ Kolektibilitas } & \multirow[t]{2}{*}{ Total kredit } & \multirow[t]{2}{*}{$\%$} \\
\hline & Lancar & $\begin{array}{c}\text { Dalam } \\
\text { Perhatian } \\
\text { Khusus } \\
\text { (DPK) }\end{array}$ & $\begin{array}{l}\text { Kurang } \\
\text { Lancar }\end{array}$ & $\begin{array}{c}\text { Diragu } \\
\text { kan }\end{array}$ & Macet & & \\
\hline 2013 & 133.803 & 986 & 0 & 38 & 1.099 & 135.929 & 0,84 \\
\hline 2014 & 149.777 & 1.577 & 150 & 24 & 1.812 & 153.342 & 1,30 \\
\hline 2015 & 158.597 & 1.717 & 160 & 182 & 2.962 & 163.620 & 2,02 \\
\hline 2016 & 167.496 & 745 & 63 & 380 & 2.339 & 171.025 & 1,66 \\
\hline 2017 & 185.798 & 1.876 & 27 & 457 & 2.179 & 190.339 & 1,40 \\
\hline
\end{tabular}

Sumber :PT. BPD Sumbar Cabang Alahan Panjang Kabupaten Solok

Berdasarkan tabel kolektibilitas kredit modal kerja BPD Sumbar Cabang Alahan Panjang Kabupaten Solok diatas, terlihat bahwa tingkat kesehatan bank BPD Sumbar Cabang Alahan Panjang Kabupaten Solok menggunakan Rasio Non Performing Loan (NPL) dari tahun 2013 sampai dengan tahun 2017 selalu berada dibawah 5\%. Artinya, BPD Sumbar Cabang Alahan Panjang Kabupaten Solok dalam mengelola kreditnya selalu melakukannya dengan baik, sehingga nilai NPL yang dimilikinya dari tahun 2013 sampai dengan tahun 2017 selalu rendah atau bisa dikatakan BPD Sumbar Cabang Alahan Panjang Kabupaten Solok adalah bank yang sehat karena terbukti berdasarkan penilaian tingkat kesehatan bank menggunakan Rasio Non Performing Loan (NPL) sesuai dengan Surat Edaran Bank Indonesia (BI) menetapkan nilai NPL maksimum adalah sebesar 5\%, apabila bank melebihi batas yang diberikan maka bank tersebutdikatakan tidak sehat.(SE BI Nomor 12/ 11 /DPNP tanggal 31 Maret 2010). 


\section{Penyelesaian Kredit Bermasalah}

MenurutWangsit, (2017)penyelesaian kredit bermasalah adalah serangkaian tindakan yang dapat dilakukan bank terhadap debitur bermasalah untuk dapat memperbaiki kinerja usaha debitur yang bersangkutan dan kualitas kreditnya.Tindakan bank dalam upaya menyelesaikan kredit bermasalah antara lain sebagai berikut:

1. Rescheduling (penjadwalan ulang), yaitu perubahan syarat kredit hanya menyangkut jadwal pembayaran dan atau jangka waktu termasuk masa tenggang (grace period) dan perubahan besarnya angsuran kredit.

2. Reconditioning (persyaratan ulang), yaitu perubahan sebagian atau seluruh syarat kredit yang tidak terbatas pada perubahan jadwal pembayaran, jangka waktu, tingkat suku bunga, penundaan pembayaran sebagian atau seluruh bunga dan persyaratan lainnya.

3. Restructuring (rekstrukturisasi), yaitu upaya penyelamatan dengan melakukan perubahan syarat-syarat kredit yang menyangkut penambahan dana bank, konversi seluruh atau sebagian tunggakan bunga menjadi pokok kredit baru atau konversi seluruh atau sebagian dari kredit menjadi equity perusahaan atauequity bank, yang dilakukan tanpa rescheduling atau reconditioning.

\section{SIMPULAN}

a) Pada umumnya jenis kredit yang ada pada PT. BPD Sumbar Cabang Alahan Panjang Kabupaten Solok ada tiga yaitu kredit modal kerja, kredit investasi dan kredit konsumtif. Tetapi, penelitian ini difokuskan kepada kredit modal kerja BPD Sumbar Cabang Alahan Panjang Kabupaten Solok.

b) Penyebab terjadinya kredit bermasalah pada PT. BPD Cabang Alahan Panjang Kabupaten Solok yaitu adanya adanya faktor eksternal yang terjadi menimpa nasabah, yaitu nasabah mengalami gagal panen karena perubahan cuaca, sehingga tanaman milik nasabah banyak yang rusak bahkan mati dan pada akhirnya hasil panen tidak sesuai harapan.

c) Langkah-langkah dalam penyelesaian kredit bermasalah pada BPD Sumbar Cabang Alahan Panjang Kabupaten Solok ada tiga cara yaitu Rescheduling (penjadwalan kembali), Reconditioning (persyaratan kembali) dan Restructuring (penataan ulang).

\section{DAFTAR PUSTAKA}

Ahmad, C. (2016). Merumuskan Visi Dan Misi Lembaga Pendidikan. Jurnal Ilmiah Saintikom, 15(1), 53-68.

Amelia, L., \& Marlius, D. (2018). Pengendalian Kredit Dalam Upaya Menciptakan Bank Yang Sehat Pada PT. Bank Pembangunan Daerah Sumatera Barat Cabang Utama Padang. https://doi.org/10.31227/osf.io/kpc64

Andriani, B., \& Susanto, R. (2019). Pengawasan Kredit PT. Bank Perkreditan Rakyat (BPR) Ophir Pasaman Barat. https://doi.org/10.31219/osf.io/aunvc 
Alanshari, F., \& Marlius, D. (2018). Prosedur Pemberian Kredit KPR Pada PT. Bank Tabungan Negara (Persero) TBK Cabang Pembantu Bukittinggi. https://doi.org/10.31227/osf.io/rsfhc

Bambang, C. P. (2014). Pengamanan Pemberian Kredit Bank Dengan Jaminan Hak Guna Bangunan. Jurnal Cita Hukum, 2(2), 273-288. https://doi.org/10.15408/jch.v1i2.1468

Baiya, \& Fernos, J. (2019). Analisis Faktor-Faktor Penyebab Kredit Macet Pada Bank Nagari Cabang Siteba. https://doi.org/10.31227/osf.io/4xuks

Chadijah, R. L. (2017). Penyelesaian Kredit Macet Bank melalui Parate Eksekusi. Jurnal Ilmu Hukum, 19(1), 81-96.

Darmawanto, \& Fernos, J. (2019). Prosedur Pemberian Kredit Pada Bank Nagari Cabang Sijunjung. https://doi.org/10.31227/osf.io/psqfy

Firmansyah, A., \& Fernos, J. (2019). Analisis Kredit Bermasalah Dilihat Dari Standar Non Performing Loan (NPL) Pada PT. Bank Perkreditan Rakyat (BPR) Prima Mulia Anugrah Cabang Padang. https://doi.org/10.31227/osf.io/gcj94

Gammahendra, F. (2014). Pengaruh Struktur Organisasi terhadap Efektivitas Organisasi. Jurnal Administrasi Bisnis (JAB), 7(2), 1-10.

Ikbal, M., \& Marlius, D. (2017). Pengaruh Jumlah Taksiran Dan Uang Pinjaman Terhadap Laba Bersih Pada PT. Pegadaian (UPC) Gurun Laweh. https://doi.org/10.31227/osf.io/uch4a

M. Fitri, R. (2002). Analisis Pemakaian Jasa Kredit Pada PERUM Pegadaian Kantor Wilayah Medan. Jurnal Ilmiah Manajemen Dan Bisnis, 2(1).

Metia, W. M. (2014). Pengalihan Tugas Pengaturan Dan Pengawasan Perbankan Dari Bank Indonesia Kepada Otoritas Jasa Keuangan Berdasarkan Undangundang Nomor 21 Tahun 2011 Tentang Otoritas Jasa Keuangan. Jurnal Ekonomi, 22(2), 75-92.

Mutiara, N. H. (2016). Faktor-faktor Bank Dalam Memberikan Pinjaman Kredit Dengan Jaminan Barang Komoditas. Jurnal Privat Law, 1(1), 42-46.

Ni Made Dwi, W. (2014). Pengaruh Penilaian Kredit Terhadap Keputusan Pemberian Kredit pada BPR. Jurnal Bisma, 2(2005).

Nurul, F. (2012). Analisis Kebijakan Pemberian Kredit Dan Pengaruh Non Performing Loan Terhadap Loan To Deposit Ratio Pada Pt. Bank Rakyat Indonesia (Persero), Tbk Cabang Rantau, Aceh Tamiang. ( Periode 20072011). Jurnal Ekonomi Dan Keuangan, Vol.1, No.1, 1(1), 88-101.

Olyvia, D. (2013). Faktor-faktor Penyebab Kredit Bermasalah Di PT. Bank Sulut 
Cabang Utama Manado. Jurnal Emba, 1(4), 69-77.

Pebriani, U. (2015). Jurnal keuangan dan perbankan. Jurnal Akuntansi, Keuangan Dan Perbankan, 1(3), 187-194.

Peraturan Otoritas Jasa Keuangan Nomor 11 POJK.03/2016. (2016). Otoritas Jasa Keuangan Republik Indonesia, 1-29.

Rahmad, N. R. M. (2015). Analisis Sistem Pemberian Kredit Kupedes Dalam Upaya Menurunkan Tingkat Non Performing Loan ( NPL ) ( Studi Pada PT . Bank Rakyat Indonesia Unit Bangsal Cabang Mojokerto ). Jurnal Administrasi Bisnis (JAB), 23(1), 1-7.

Randy, Q. P. J. (2014). Analisis Kinerja Laporan Keuangan Perusahaan Dan Penilaian Agunan Dalam Keputusan Pemberian Kredit Modal Kerja Pada PT. Bank Rakyat Indonesia (PERSERO) Tbk Cabang Manado. Jur EMBA, 2(2), 1594-1606.

Ratna, B. (2013). Analisis sistem dan prosedur pemberian kredit modal kerja dalam upaya mendukung pengendalian kredit. Jurnal Administrasi Bisnis, $1-10$.

Saduldyn, P. (2013). Analisis Pemberian Kredit Mikro Pada Bank Syariah Mandiri Cabang Manado. Jurnal EMBA, 1(4), 875-885. https://doi.org/10.1017/CBO9781107415324.004

SE BI Nomor 12/ $11 /$ DPNP tanggal 31 Maret 2010. (n.d.). Surat Edaran Bank Indonesia tahun 2010. Tentang Kredit Perbankan. Nomor 12/ 11 /DPNP tanggal 31 Maret 2010 Lampiran 14. Jurnal Ekonomi Dan Keuangan, Vol.1, No.1.

Sjafitri, H. (2011). Faktor-faktor yang mempengaruhi kualitas kredit dalam dunia perbankan. Jurnal Manajemen Dan Kewirausahaan, 2(2), 106-120.

Suliyanto. (2014). Perbandingan Efisiensi Bank Perkreditan Rakyat Dan Bank Umum Dengan Pendekatan Data Envelopment Analysis. Jurnal Keuangan Dan Perbankan, 18(2), 297-306.

Undang-undang RI Nomor 10. (1998). Undang-undang Republik Indonesia Nomor 10 Tahun 1998 Tentang Perubahan Atas Undang-undang Nomor 7 Tahun 1972 Tentang Perbankan.

Uswatun, K. (2012). Pengendalian Manajemen Pemberian Kredit Modal Kerja Dalam Upaya Meminimalkan Kredit Bermasalah. Jurnal Administrasi Bisnis, 26(1), 1-10.

Wangsit, S. (2017). Analisis Prioritas Penanganan Kredit Bermasalah Dalam Rangka Menyehatkan Kualitas Kredit Pada Bank Perkreditan Rakyat. Jurnal Widya Cipta, IX(1), 8-17. 
Widayati, R. (2019). Pelaksanaan Prinsip Kehati-Hatian Dalam Pemberian Kredit Konsumtif Pada Bank Nagari Cabang Siteba. https://doi.org/10.17605/OSF.IO/FZVXR

Widayati, R. (2019). Aktivitas Pemberian Kredit Komersil Pada Bank Nagari Cabang Sijunjung. https://doi.org/10.17605/OSF.IO/QTVZ9

Widayati, R. (2019). Pelaksanaan Kredit Pada Bank Perkreditan Rakyat LPN Pasar Baru Durian Sawahlunto. https://doi.org/10.17605/OSF.IO/5HPAB

Widayati, R. (2019). Upaya Penanganan Kredit Bermasalah Pada Bank Nagari Cabang Utama Padang. https://doi.org/10.17605/OSF.IO/YJ3KN

Widya, R. (2016). Evaluasi Kelayakan Pemberian Kredit Usaha Rakyat Untuk Mencegah Terjadinya Kredit Bermasalah (Studi Kasus Pada PT. Bank Rakyat Indonesia (Persero), Tbk. Cabang Kawi Malang). Jurnal Administrasi Bisnis (JAB), 39(2), 34-42.

Yoda, D. (2008). Pengaruh Tingkat Suku Bunga, Nilai Tukar Rupiah Dan Jumlah Ekspor Terhadap Tingkat Kredit Perbankan. Journal of Applied Finance and Accounting, 1(1), 166-192.

Yoli, L. S. (2013). Pengaruh Dana Pihak Ketiga, Kecukupan Modal Dan Risiko Kredit Terhadap Profitabilitas (Perusahaan Perbankan yang Terdaftar di BEI). Jurnal Akuntansi, 1(2). 